Theories \& Applications, the International Edition

Printed Version: (ISSN 2090-5262)

Online Version: (ISSN 2090-5270)

November 2012, Volume 2, No. 3 Pages (74 - 91)

\title{
Dynamics of Enhancement Some Bio-kinematic Parameters for the Long Jump Contestants in Egypt
}

Abdel-Moneim Ibrahim Haridi*, Suzan Salah Eldin Tantawy**, Abdel-Rahman Akl***

\begin{abstract}
:
The current study aims to analyze the performance of long jump contestants (under 16, under18, under 20 years and the high level) during national championships, The study attempted to determine the values of some kinematic variables of the final approaching phase (last twosteps) and takeoff for long jump contestants (under16, under18, under20 and high level) and comparing kinematic variables for different age groups to determine the dynamics of enhancement for some variables affecting performance in the long jump. The sample consisted of twenty three contestants from the national champions, Data was collected by means of measurement, video recording and movement analysis. As a results, 1- Rate of horizontal acceleration and resultant velocity directly before takeoff, increase as the age group gets higher but there is no significant difference between ages 18 and 20 years, 2- Rate of horizontal and vertical velocity at the moment of takeoff increases as age group gets higher for the sample individuals but there is no significant difference between ages 18 and 20 years and high levelin vertical velocity but it is present between 16 years old group and others, 3 - A great rate of loss inhorizontal and vertical velocity for all contestants at takeoff more that at the last step before takeoff ranging between $0.40 \mathrm{~m} / \mathrm{s}-0.67 \mathrm{~m} / \mathrm{s}$.
\end{abstract}

Keywords: kinematics, long jump, motion analysis

\section{Introduction:}

$\mathrm{L}$ ately it had been the interest to find methods to apply rules and scientific theories that had been formulated in Physics, Mechanics and Biology to the human movement in general and athletes in particular after holding many international conferences that lead to a great development the level of human motor performance also scientists have pointed that the is the method to finding deal solution to different motor skill and technical performance problems in an effort to reach the best method possible by which the human system would achieve great achievements and

\footnotetext{
* Professor Emeritus, Track and Field Events Training Department, Faculty of Physical Education for Boys, Alexandria University, Egypt.

** Assistant Professor, Sports Training and Kinesiology Department, Faculty of Physical Education for Girls, Alexandria University, Egypt.

*** Assistant Lecturer, Foundations of Physical Education Department, Faculty of Physical Education for Boys, Alexandria University, Egypt.
}

the highest possible athletic (Wood, $\mathrm{j}$. et al (36)), (DempesterW,et al (9)), (Alexander, R. \&Vernon ,A (5)).

The long Jump is one of competitions in Athletics and depends in its rating on quantitative values, and could be measured subjectively through some Biomechanical parameters as takeoff velocity,takeoff angleand the height of the center of mass from the ground which lead to enhancing the performance in the long jump. (Kassem, H.(19)), (Bastawisi, A (7)), (Lees , A. et al (20)), (Bhowmick (8)).

The use of more than one part of the body of the athlete at the same time requires a high level of neuromuscular compatibility in order to perform the skill with perfection while economizing on the effort exerted through regulating the mutual neuro-modulations ranging between excitation and stopping (Gamal, M. \&Nahed, A.(11)). 
The long Jump consists of four main stages as follows:

1. Approaching (getting ready to takeoff).

2. Takeoff (getting ready for flight).

3. Flight (result of takeoff).

4. Touchdown (outcome of flight).

Theses stages are connected and are difficult to separate, still there are many details related to each of the previous stages individually that interact and integrate to form a basis to the following stages as the formation and effectiveness of each portion is closely linked to its precedent in terms of success, effectiveness or failure, and also because it is the basis of the formation of the following portions which becomes the basis for what follows and so on in other words all portions contribute to the whole achievement.

Because of the high velocity that characterizes the competitions of the long jump. Performance parameters can only be judged through accurate methods of measurement, thus the elevation of the level of skill performance depends primarily on the accuracy of the measurement equipment of the bio-mechanical characteristics of the movement. (Gamal, M. \&Nahed, A.(11)).

The technological development and the information revolution have both lead to consequent development in the systems controlling all analysis data on computers through accurate processing of information which is the complete electronic control of all data and information related to quantitative description of the sports skill. The connection of videotaping to computer programs is considered one of the most accurate methods of acquiring variables of motor analysis in the least possible time and with the least effort and expense (Adrian, M. , \& Cooper , j (2)).

The coach has to have all information related to properties of skill performance to facilitate its development, which is revealing the interrelations between the movement of all body parts while performing the skill which cannot be acquired unless by monitoring and bio- mechanically analyzing every competitor movements throughout all stages of performing the skill. (Usama, M. (35))

Thus, it's of great importance that there should be enough data base and regularly updated information on the long jump performance skills to adjust the training process and so he motor problems. The current study aims to analyze performance skills of the long jump contestants (under 16, under 18, under 20 years of age and the high level) during the national championship.

\section{Aims of study:}

1. Determining values of some special kinematic variables during the stage of approaching (last two steps) and takeoff for long jump contestants (under 16, under 18, under 20 years of age and the high level).

2. Comparing values of kinematic variables for different age groups to determine the dynamics of enhancement of variables affecting the long jump performance.

\section{Methods:}

\section{Subjects:}

Twenty three contestants werecompiled by specific selection of national championships contestants 2008 in the first six positions for all age groups included in the study (under 16, under 18 , under20 years and five contestants for the high level).

Contestants were specifically selected for the following reasons:

-Uniqueness off the contestants the study sample having the best national achievement levels for all age groups.

- Contestants participating regularly in local and national competitions.

-All contestants in the study sample are members in the national league of Athletics. 
Table (1)

The description of contestants

\begin{tabular}{|c|c|c|c|}
\hline Body measurements & Age stage & Mean & Std. Deviation \\
\hline \multirow{4}{*}{ Body volume(kg) } & Under 16 years & 59.17 & 5.27 \\
\hline & Under 18 years & 65.33 & 3.08 \\
\hline & Under 20 years & 67.50 & 4.76 \\
\hline & High level & 70.00 & 13.3 \\
\hline \multirow{4}{*}{ Total length $(\mathrm{cm})$} & Under 16 years & 168.5 & 2.27 \\
\hline & Under 18 years & 174.83 & 5.15 \\
\hline & Under 20 years & 179.83 & 5.43 \\
\hline & High level & 181.60 & 7.54 \\
\hline \multirow{4}{*}{ Arm length (cm) } & Under 16 years & 31.33 & 1.75 \\
\hline & Under 18 years & 34.17 & 0.41 \\
\hline & Under 20 years & 34.17 & 2.32 \\
\hline & High level & 33.60 & 2.51 \\
\hline \multirow{4}{*}{ Forearm length $(\mathrm{cm})$} & Under 16 years & 29.83 & 0.98 \\
\hline & Under 18 years & 30.50 & 1.76 \\
\hline & Under 20 years & 31.17 & 2.40 \\
\hline & High level & 29.60 & 1.82 \\
\hline \multirow{4}{*}{ Hand length (cm) } & Under 16 years & 18.83 & 0.98 \\
\hline & Under 18 years & 18.83 & 1.60 \\
\hline & Under 20 years & 18.50 & 1.38 \\
\hline & High level & 18.80 & 0.84 \\
\hline \multirow{4}{*}{ Thigh length $(\mathrm{cm})$} & Under 16 years & 50.00 & 2.76 \\
\hline & Under 18 years & 52.67 & 3.98 \\
\hline & Under 20 years & 53.83 & 4.54 \\
\hline & High level & 59.60 & 6.03 \\
\hline \multirow{4}{*}{ leg length $(\mathrm{cm})$} & Under 16 years & 43.83 & 2.40 \\
\hline & Under 18 years & 45.33 & 4.37 \\
\hline & Under 20 years & 47.17 & 3.13 \\
\hline & High level & 43.40 & 2.61 \\
\hline \multirow{4}{*}{ Foot length $(\mathrm{cm})$} & Under 16 years & 24.83 & 0.98 \\
\hline & Under 18 years & 27.33 & 1.37 \\
\hline & Under 20 years & 27.00 & 1.41 \\
\hline & High level & 28.80 & 1.1 \\
\hline
\end{tabular}

\section{Procedures:}

Kinematic data were collected using2 Video cameras (fixed), (The first is a "Panasonic (M.3000)" made in Japan with a frequency of $25 \mathrm{~Hz}$, used to determine the variables of the last two steps, The second is a "JVC GR - DVL 9800 " made in Japan with a frequency of 240 $\mathrm{Hz}$, used to determine the variables of the takeoff),( Figure 1), Video point 2.5 software for movement analysis, Choosing the best tries for each contestant to analyze them, and Calculating the average weight of different body parts in relation to the total body weight, as well as the center of mass for different body parts in relation to their length, measured from the inter joints according to Clauser et al 1969 Tables. 
Figure (1)

Camera positions while capture

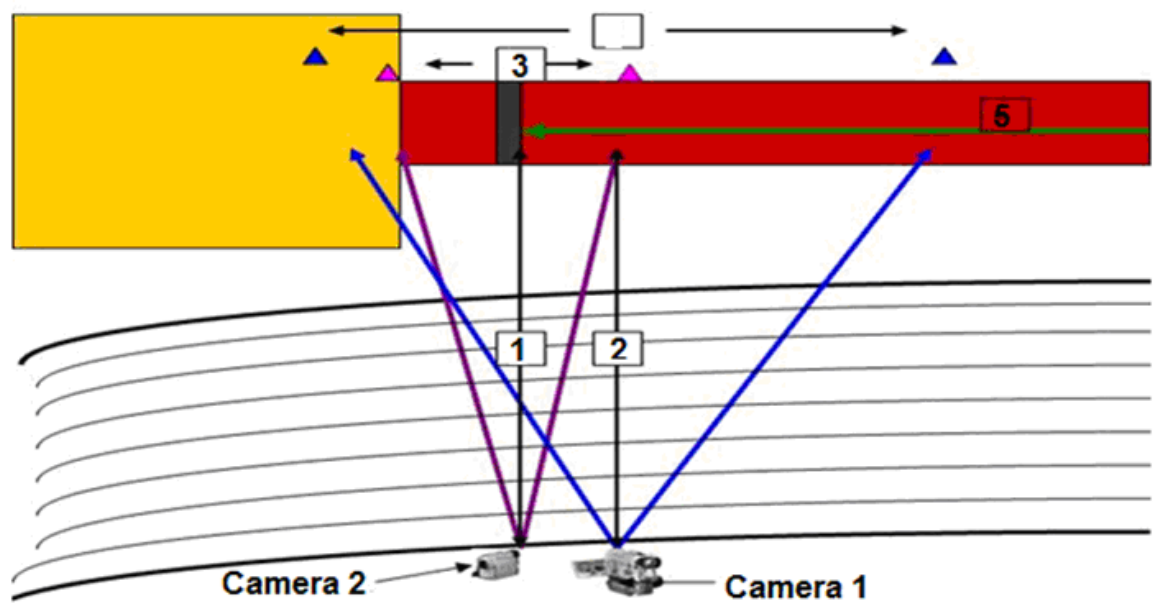

-Range of shooting for the second camera.

-Range of shooting for the first camera.

- Distance between second camera and the range of capturing, (frequency $240 \mathrm{~Hz}$ ).

\section{Biomechanicalvariables:}

VR1 The pre- final stride resultant velocity

VR2 The final stride resultant velocity

D1 The pre- final stride space distance length

D2 The final stride space length

D3 The horizontal takeoff distance (it's the space between the body center of mass at touchdown to the body center of mass at takeoff

$\mathrm{H}_{1} \quad$ the body center of mass height at touch down

$\mathrm{H}_{2}$ the body center of mass height at takeoff

$\mathrm{H}_{3}$ The vertical displacement of the center of mass (the difference between $\mathrm{H} 2-\mathrm{H} 1=\mathrm{H} 3$ )

VxTD The horizontal velocity at touch down

VYTD The vertical velocity at touch down

VRTD The resultant velocity at touch down

VxTO The horizontal velocity at takeoff

VyTO The vertical velocity at takeoff

VRTO The resultant velocity at takeoff

$\theta \quad$ The flight angle

$\mathrm{T} \quad$ The total takeoff time

T1 The time of touchdown to the maximum bending

$\mathrm{T}_{2} \quad$ The time of the maximum bending moment to takeoff

\section{Statistical analysis:}

The researchers used the (SPSS v 16.0) program for statistical analysis to test data statistically using:
-Distance between first camera and the range of capturing, (frequency $25 \mathrm{~Hz}$ ).

-Direction of motion. 
Results:

Showing statistical description for jump distances for sample; Table (2) shows:

Average jump distance for sample under study in age groups (under 16, under 18, under 20 and high level) was as follows:
$(5.75 \mathrm{~m}+0.26 \mathrm{~m}, \quad 6.25 \mathrm{~m}+0.32 \mathrm{~m}, \quad 6.52 \mathrm{~m}+0.17 \mathrm{~m}$, $6.97 \mathrm{~m}+0.37 \mathrm{~m})$ consecutively. It is clear also that least views for distance of jump and most views ranges from the least to the longest distance according to the increase in age from youngest to elder for contestants in the study.

Table (2)

The statistical description of the jumping distances

\begin{tabular}{|c|c|c|c|}
\hline Variables & Age stage & Mean & Std. Deviation \\
\hline \multirow{3}{*}{ Jump distance (m) } & Under 16 years & 5.75 & 0.26 \\
\cline { 2 - 4 } & Under 18 years & 6.25 & 0.32 \\
\cline { 2 - 4 } & Under 20 years & 6.52 & 0.17 \\
\cline { 2 - 4 } & High level & 6.97 & 0.37 \\
\hline
\end{tabular}

Table (3)

The analysis of variance for jumping distances

\begin{tabular}{|c|c|c|c|c|c|}
\hline \multirow{2}{*}{ Kinematic variables } & $\begin{array}{c}\text { Difference } \\
\text { source }\end{array}$ & $\begin{array}{c}\text { Sum of } \\
\text { Squares }\end{array}$ & df & Mean Square & F \\
\hline \multirow{3}{*}{ Jump distance (m) } & Between Groups & 4.329 & 3 & 1.443 & \multirow{2}{*}{$* * 17.748$} \\
\cline { 2 - 5 } & Within Groups & 1.545 & 19 & .081 \\
\cline { 2 - 6 } & Total & 5.874 & 22 & & \\
\hline
\end{tabular}

Table (4)

The significant differences between means with using L.S.D for jumping distances

\begin{tabular}{|c|c|c|c|c|c|c|}
\hline \multirow{2}{*}{$\begin{array}{c}\text { Kinematic } \\
\text { variables }\end{array}$} & Age stage & Mean & $\begin{array}{c}\text { Under 16 } \\
\text { years }\end{array}$ & $\begin{array}{c}\text { Under 18 } \\
\text { years }\end{array}$ & Under 20 years & High level \\
\hline \multirow{3}{*}{$\begin{array}{c}\text { The jump distance } \\
(\mathrm{m})\end{array}$} & Under 16 years & 6.25 & & $0.49667(*) \uparrow$ & $0.77000(*) \uparrow$ & $1.22167(*) \uparrow$ \\
\cline { 2 - 7 } & Under 18 years & 8.52 & & & 0.27333 & $0.72500(*) \uparrow$ \\
\cline { 2 - 7 } & Under 20 years & 6.97 & & & & $0.45167(*) \uparrow$ \\
\cline { 2 - 7 } & High level & 6.25 & & & & \\
\hline
\end{tabular}

Table (5)

The statistical description for some kinematic variables related to the last strides from approaching stage

\begin{tabular}{|c|c|c|c|}
\hline Kinematic variables & Age stage & Mean & Std. Deviation \\
\hline \multirow{4}{*}{$\begin{array}{c}\text { The pre- final stride resultant } \\
\text { velocity(m/s)(VR1) }\end{array}$} & Under 16 years & 7.04 & 0.29 \\
\cline { 2 - 4 } & Under 18 years & 8.28 & 0.89 \\
\cline { 2 - 4 } & Under 20 years & 8.85 & 0.64 \\
\cline { 2 - 4 } & High level & 9.84 & 0.96 \\
\hline \multirow{4}{*}{$\begin{array}{c}\text { The pre- final stride length } \\
\text { The resultant velocity of body } \\
\text { center of mass in moment of } \\
\text { the final stride starts (m/s). } \\
\text { (VR2) }\end{array}$} & Under 16 years & 2.11 & 0.10 \\
\cline { 2 - 4 } & Under 18 years & 2.16 & 0.08 \\
\cline { 2 - 4 } & Under 20 years & 2.15 & 0.12 \\
\cline { 2 - 4 } & Under 16 years & 7.19 & 0.35 \\
\cline { 2 - 4 } & Under 18 years & 8.08 & 0.49 \\
\cline { 2 - 4 } & Under 20 years & 8.64 & 0.10 \\
\hline \multirow{3}{*}{$\begin{array}{c}\text { The final stride length (m). } \\
\text { (D2) }\end{array}$} & Under 16 years & 2.05 & 0.35 \\
\cline { 2 - 4 } & Under 18 years & 2.09 & 0.08 \\
\cline { 2 - 4 } & Under 20 years & 2.10 & 0.13 \\
\cline { 2 - 4 } & High level & 2.00 & 0.10 \\
\hline
\end{tabular}


Table (6)

The analysis of variance for the Bio kinematic variables related to the final two strides from the approaching stage

\begin{tabular}{|c|c|c|c|c|c|}
\hline Kinematic variables & Difference source & $\begin{array}{c}\text { Sum of } \\
\text { Squares }\end{array}$ & df & Mean Square & $\mathbf{F}$ \\
\hline \multirow{3}{*}{$\begin{array}{l}\text { The resultant velocityof the body center } \\
\text { of mass in the pre-final stride starting } \\
\text { moment }(\mathrm{m} / \mathrm{s}),(\mathrm{VR} 1)\end{array}$} & Between Groups & 22.705 & 3 & 7.567 & \multirow{3}{*}{ (*) 14.284} \\
\hline & Within Groups & 10.066 & 19 & 0.530 & \\
\hline & Total & 32.768 & 22 & & \\
\hline \multirow{3}{*}{ The pre-final stride length (m),(D1) } & Between Groups & 0.009 & 3 & 0.003 & \multirow{3}{*}{0.086} \\
\hline & Within Groups & 0.648 & 19 & 0.0343 & \\
\hline & Total & 0.657 & 22 & & \\
\hline \multirow{3}{*}{$\begin{array}{l}\text { The resultant velocityof the body center } \\
\text { of mass in the final stride starting } \\
\text { moment }(\mathrm{m} / \mathrm{s})(\mathrm{VR} 2)\end{array}$} & Between Groups & 21.067 & 3 & 7.022 & \multirow{3}{*}{ (*) 18.072} \\
\hline & Within Groups & 7.383 & 19 & 0.389 & \\
\hline & Total & 28.450 & 22 & & \\
\hline \multirow{3}{*}{ The final stride length (m), (D2) } & Between Groups & 0.034 & 3 & 0.011 & \multirow{3}{*}{0.501} \\
\hline & Within Groups & 0.431 & 19 & 0.023 & \\
\hline & Total & 0.465 & 22 & & \\
\hline
\end{tabular}

Table (7)

The significant differences between means with using L.S.D forthe Bio kinematic variables related to the final two strides from the approaching stage

\begin{tabular}{|c|c|c|c|c|c|c|}
\hline \multirow{2}{*}{ Kinematic variables } & \multirow{2}{*}{ Age stage } & \multirow{2}{*}{ Mean } & \multicolumn{4}{|c|}{ Mean Difference } \\
\hline & & & $\begin{array}{c}\text { Under } \\
16 \text { years }\end{array}$ & $\begin{array}{c}\text { Under } 18 \\
\text { years }\end{array}$ & $\begin{array}{c}\text { Under } 20 \\
\text { years }\end{array}$ & High level \\
\hline \multirow{4}{*}{$\begin{array}{l}\text { The resultant velocity of the body } \\
\text { center of mass in the pre-final } \\
\text { stride starting moment (m/s), } \\
\text { (VR1) }\end{array}$} & Under 16 years & 7.04 & & $\uparrow(*) 1.24283$ & $\uparrow(*) 1.81400$ & $\uparrow(*) 2.79757$ \\
\hline & Under 18 years & 8.28 & & & 0.57117 & $\uparrow(*) 1.55473$ \\
\hline & Under 20 years & 8.85 & & & & $\uparrow(*) 0.98357$ \\
\hline & High level & 9.84 & & & & \\
\hline \multirow{4}{*}{$\begin{array}{l}\text { The resultant velocity of the body } \\
\text { center of mass in the final stride } \\
\text { starting moment (m/s) (VR2) }\end{array}$} & Under 16 years & 7.19 & & $\uparrow(*) 0.88383$ & $\uparrow(*) 1.44667$ & $\uparrow(*) 2.71407$ \\
\hline & Under 18 years & 8.08 & & & 0.56283 & $\uparrow(*) 1.83023$ \\
\hline & Under 20 years & 8.64 & & & & $\uparrow(*) 1.26740$ \\
\hline & High level & 9.91 & & & & \\
\hline
\end{tabular}

Table (8)

The statistical description for the velocities related to the body center of mass during the takeoff stage

\begin{tabular}{|c|c|c|c|}
\hline Kinematic variables & Age stage & Mean & Std. Deviation \\
\hline \multirow{4}{*}{$\begin{array}{l}\text { The horizontal velocity of the } \\
\text { body center of mass at } \\
\text { touchdown (M/S)(VXTD) }\end{array}$} & Under 16 years & 7.61 & 0.41 \\
\hline & Under 18 years & 8.38 & 0.39 \\
\hline & Under 20 years & 8.83 & 0.56 \\
\hline & High level & 9.67 & 0.29 \\
\hline \multirow{4}{*}{$\begin{array}{c}\text { The vertical velocity of the } \\
\text { body center of mass at } \\
\text { touchdown(VYTD) }\end{array}$} & Under 16 years & 0.48 & 0.44 \\
\hline & Under 18 years & 0.43 & 0.17 \\
\hline & Under 20 years & 0.30 & 0.15 \\
\hline & High level & 0.53 & 0.40 \\
\hline \multirow{4}{*}{$\begin{array}{l}\text { The resultant velocity of body } \\
\text { center of mass at } \\
\text { touchdown }(\mathrm{m} / \mathrm{s}) \text {. (VRTD) }\end{array}$} & Under 16 years & 7.63 & 0.34 \\
\hline & Under 18 years & 8.40 & 0.39 \\
\hline & Under 20 years & 8.84 & 0.56 \\
\hline & High level & 9.70 & 0.31 \\
\hline \multirow{4}{*}{$\begin{array}{l}\text { The horizontal velocity of the } \\
\text { body center of mass at takeoff } \\
(\mathrm{m} / \mathrm{s})(\mathrm{VXTO})\end{array}$} & Under 16 years & 6.45 & 0.40 \\
\hline & Under 18 years & 7.43 & 0.13 \\
\hline & Under 20 years & 7.77 & 0.49 \\
\hline & High level & 8.34 & 0.45 \\
\hline \multirow{4}{*}{$\begin{array}{l}\text { The vertical velocity of the } \\
\text { body center of mass at takeoff } \\
(\mathrm{m} / \mathrm{s})(\mathrm{VYTO})\end{array}$} & Under 16 years & 2.44 & 0.34 \\
\hline & Under 18 years & 2.94 & 0.48 \\
\hline & Under 20 years & 3.06 & 0.38 \\
\hline & High level & 3.44 & 0.34 \\
\hline \multirow{4}{*}{$\begin{array}{l}\text { The resultant velocity of the } \\
\text { body center of mass at takeoff } \\
(\mathrm{m} / \mathrm{s}) \text {. (VRTO) }\end{array}$} & Under 16 years & 6.99 & 0.41 \\
\hline & Under 18 years & 8.00 & 0.23 \\
\hline & Under 20 years & 8.35 & 0.53 \\
\hline & High level & 9.03 & 0.32 \\
\hline
\end{tabular}


Table (9)

The analysis of variance for the velocities related to the body center of mass during the takeoff stage

\begin{tabular}{|c|c|c|c|c|c|}
\hline Kinematic variables & Difference source & $\begin{array}{c}\text { Sum of } \\
\text { Squares }\end{array}$ & df & $\begin{array}{c}\text { Mean } \\
\text { Square }\end{array}$ & $\mathbf{F}$ \\
\hline \multirow{3}{*}{$\begin{array}{l}\text { The horizontal velocity of the body } \\
\text { center of massat touchdown } \\
(\mathrm{m} / \mathrm{s})(\mathrm{VXTD})\end{array}$} & Between Groups & 12.243 & 3 & 4.081 & \multirow[b]{3}{*}{ (*) 21.876} \\
\hline & Within Groups & 3.544 & 19 & 0.187 & \\
\hline & Total & 15.787 & 22 & & \\
\hline \multirow{3}{*}{$\begin{array}{l}\text { The vertical velocity of the body } \\
\text { center of massat touchdown (VYTD) }\end{array}$} & Between Groups & 0.163 & 3 & 0.054 & \multirow{3}{*}{0.560} \\
\hline & Within Groups & 1.845 & 19 & 0.097 & \\
\hline & Total & 2.008 & 22 & & \\
\hline \multirow{3}{*}{$\begin{array}{l}\text { The resultant velocityof body center } \\
\text { of massat touchdown(m/s). (VRTD) }\end{array}$} & Between Groups & 12.183 & 3 & 4.061 & \multirow{3}{*}{ (*)21.245 } \\
\hline & Within Groups & 3.632 & 19 & 0.191 & \\
\hline & Total & 15.815 & 22 & & \\
\hline \multirow{3}{*}{$\begin{array}{l}\text { The horizontal velocity of the body } \\
\text { center of massat takeoff }(\mathrm{m} / \mathrm{s}) \\
\text { (VXTO) }\end{array}$} & Between Groups & 9.460 & 3 & 3.153 & \multirow{3}{*}{ (*)17.995 } \\
\hline & Within Groups & 3.329 & 19 & 0.175 & \\
\hline & Total & 12.789 & 22 & & \\
\hline \multirow{3}{*}{$\begin{array}{l}\text { The vertical velocity of the body } \\
\text { center of massat takeoff }(\mathrm{m} / \mathrm{s})(\mathrm{VYTO})\end{array}$} & Between Groups & 2.875 & 3 & 0.958 & \multirow{3}{*}{ (*)5.732 } \\
\hline & Within Groups & 3.176 & 19 & 0.167 & \\
\hline & Total & 6.051 & 22 & & \\
\hline \multirow{3}{*}{$\begin{array}{l}\text { The resultant velocityof the body } \\
\text { center of massat takeoff } \\
(\mathrm{m} / \mathrm{s})(\mathrm{VRTO})\end{array}$} & Between Groups & 12.175 & 3 & 4.058 & \multirow{3}{*}{ (*) 26.520} \\
\hline & Within Groups & 2.907 & 19 & 0.153 & \\
\hline & Total & 15.082 & 22 & & \\
\hline
\end{tabular}


Table (10)

The significant differences between means with using L.S.D for the velocities related to the body center of mass during the takeoff stage

\begin{tabular}{|c|c|c|c|c|c|c|}
\hline \multirow[b]{2}{*}{ Kinematic variables } & \multirow[b]{2}{*}{ Age stage } & \multirow[b]{2}{*}{ Mean } & \multicolumn{4}{|c|}{ Mean Difference } \\
\hline & & & $\begin{array}{c}\text { Under } \\
16 \text { years }\end{array}$ & $\begin{array}{c}\text { Under } 18 \\
\text { years }\end{array}$ & $\begin{array}{c}\text { Under } 20 \\
\text { years }\end{array}$ & High level \\
\hline \multirow{4}{*}{$\begin{array}{c}\text { The horizontal velocity of the } \\
\text { body center of massat } \\
\text { touchdown }(\mathrm{m} / \mathrm{s})(\mathrm{VXTD})\end{array}$} & $\begin{array}{c}\text { Under } 16 \\
\text { years }\end{array}$ & 7.61 & & $\uparrow(*) 0.77483$ & $\uparrow(*) 1.222$ & $\uparrow(*) 2.06443$ \\
\hline & $\begin{array}{c}\text { Under } 18 \\
\text { years }\end{array}$ & 8.38 & & & 0.44683 & $\uparrow(*) 1.28960$ \\
\hline & $\begin{array}{c}\text { Under } 20 \\
\text { years }\end{array}$ & 8.83 & & & & $\begin{array}{c}\uparrow(*) \\
0.84277\end{array}$ \\
\hline & High level & 9.67 & & & & \\
\hline \multirow{4}{*}{$\begin{array}{c}\text { The resultant velocity of the } \\
\text { body center of mass at } \\
\text { touchdown }(\mathrm{m} / \mathrm{s})(\mathrm{VXTD})\end{array}$} & $\begin{array}{c}\text { Under } 16 \\
\text { years }\end{array}$ & 7.634 & & $\uparrow(*) 0.763333$ & $\uparrow(*) 1.20283$ & $\uparrow(*) 2.06160$ \\
\hline & $\begin{array}{c}\text { Under } 18 \\
\text { years }\end{array}$ & 7.634 & & & 0.43950 & $\uparrow(*) 1.29827$ \\
\hline & $\begin{array}{c}\text { Under } 20 \\
\text { years }\end{array}$ & 8.40 & & & & $\uparrow(*) 0.85877$ \\
\hline & High level & 9.70 & & & & \\
\hline \multirow{4}{*}{$\begin{array}{l}\text { The horizontal velocity of the } \\
\text { body center of massat } \\
\text { takeoff }(\mathrm{m} / \mathrm{s}) \text { (VXTO) }\end{array}$} & $\begin{array}{c}\text { Under } 16 \\
\text { years }\end{array}$ & 6.54 & & $\uparrow(*) 0.88750$ & $\begin{array}{c}\uparrow(*) \\
1.22867\end{array}$ & $\uparrow(*) 1.79343$ \\
\hline & $\begin{array}{c}\text { Under } 18 \\
\text { years }\end{array}$ & 7.43 & & & 0.34117 & $\uparrow(*) 0.90593$ \\
\hline & $\begin{array}{c}\text { Under } 20 \\
\text { years }\end{array}$ & 7.77 & & & & $\begin{array}{c}\uparrow(*) \\
0.56477\end{array}$ \\
\hline & High level & 8.34 & & & & \\
\hline \multirow{4}{*}{$\begin{array}{l}\text { The verticalvelocity of the } \\
\text { body center of massat } \\
\text { takeoff }(\mathrm{m} / \mathrm{s})(\mathrm{VYTO})\end{array}$} & $\begin{array}{l}\text { Under } 16 \\
\text { years }\end{array}$ & 2.44 & & $\uparrow(*) 0.50783$ & $\uparrow(*) 0.61967$ & $\uparrow(*) 1.00847$ \\
\hline & $\begin{array}{c}\text { Under } 18 \\
\text { years }\end{array}$ & 2.94 & & & 0.11183 & 0.50063 \\
\hline & $\begin{array}{c}\text { Under } 20 \\
\text { years }\end{array}$ & 3.06 & & & & 0.38880 \\
\hline & High level & 3.44 & & & & \\
\hline \multirow{4}{*}{$\begin{array}{l}\text { The resultant velocityof the } \\
\text { body center of massat } \\
\text { takeoff }(\mathrm{m} / \mathrm{s})(\mathrm{VRTO})\end{array}$} & $\begin{array}{c}\text { Under } 16 \\
\text { years }\end{array}$ & 6.99 & & $\uparrow(*) 1.01850$ & $\uparrow(*) 1.36850$ & $\uparrow(*) 2.04517$ \\
\hline & $\begin{array}{c}\text { Under } 18 \\
\text { years }\end{array}$ & 8.00 & & & 0.35000 & $\begin{array}{c}\uparrow(*) \\
1.02667\end{array}$ \\
\hline & $\begin{array}{c}\text { Under } 20 \\
\text { years }\end{array}$ & 8.35 & & & & $\begin{array}{c}\uparrow(*) \\
0.67667\end{array}$ \\
\hline & High level & 9.03 & & & & \\
\hline
\end{tabular}


Table (11)

The statistical description for some variables related to the center of mass during and takeoff distance during the takeoff

\begin{tabular}{|c|c|c|c|}
\hline Kinematic variables & Age stage & Mean & Std. Deviation \\
\hline \multirow{3}{*}{$\begin{array}{c}\text { The center of mass from the } \\
\text { ground at touchdown (m)(H1) }\end{array}$} & Under 16 years & 0.85 & 0.06 \\
\cline { 2 - 4 } & Under 18 years & 0.94 & 0.05 \\
\cline { 2 - 4 } & Under 20 years & 0.95 & 0.03 \\
\cline { 2 - 4 } & High level & 0.86 & 0.1 \\
\hline \multirow{3}{*}{$\begin{array}{c}\text { The center of mass from the } \\
\text { ground at takeoff (m)(H2) }\end{array}$} & Under 16 years & 1.05 & 0.08 \\
\cline { 2 - 4 } & Under 18 years & 1.17 & 0.14 \\
\cline { 2 - 4 } & Under 20 years & 1.18 & 0.05 \\
\cline { 2 - 4 } $\begin{array}{c}\text { The different between body } \\
\text { center of mass at }\end{array}$ & High level & 1.11 & 0.09 \\
\cline { 2 - 4 } touchdown(m/s). (VRTD) & Under 16 years & 0.20 & 0.05 \\
\cline { 2 - 4 } & Under 18 years & 0.23 & 0.10 \\
\cline { 2 - 4 } & Under 20 years & 0.23 & 0.05 \\
\hline \multirow{3}{*}{$\begin{array}{c}\text { The takeoff distance (the } \\
\text { horizontal displacement at the } \\
\text { takeoff moment).(m) (D3) }\end{array}$} & High level & 0.25 & 0.05 \\
\cline { 2 - 4 } & Under 16 years & 1.05 & 0.13 \\
\cline { 2 - 4 } & Under 18 years & 1.03 & 0.08 \\
\cline { 2 - 4 } & Under 20 years & 0.93 & 0.06 \\
\hline
\end{tabular}

Table (12)

The analysis of variance for the variables related to the body center of mass and distance of takeoff during the takeoff stage

\begin{tabular}{|c|c|c|c|c|c|}
\hline Kinematic variables & Difference source & $\begin{array}{l}\text { Sum of } \\
\text { Squares }\end{array}$ & df & $\begin{array}{c}\text { Mean } \\
\text { Square }\end{array}$ & $\mathbf{F}$ \\
\hline \multirow{3}{*}{$\begin{array}{l}\text { The center of mass height from the } \\
\text { ground at touchdown }(\mathrm{m})(\mathrm{H} 1)\end{array}$} & Between Groups & 0.047 & 3 & 0.061 & \multirow{3}{*}{ (*) 4.058} \\
\hline & Within Groups & 0.073 & 19 & 0.004 & \\
\hline & Total & 0.120 & 22 & & \\
\hline \multirow{3}{*}{$\begin{array}{l}\text { The center of mass from the ground at } \\
\text { takeoff }(\mathrm{m})(\mathrm{H} 2)\end{array}$} & Between Groups & 0.065 & 3 & 0.022 & \multirow{3}{*}{2.301} \\
\hline & Within Groups & 0.179 & 19 & 0.009 & \\
\hline & Total & 0.244 & 22 & & \\
\hline \multirow{3}{*}{$\begin{array}{l}\text { The different between body center of } \\
\text { mass in both of the starting and end of } \\
\text { takeoff moment }(\mathrm{m})(\mathrm{H} 3)\end{array}$} & Between Groups & 0.008 & 3 & 0.0031 & \multirow{3}{*}{0.549} \\
\hline & Within Groups & 0.094 & 19 & 0.005 & \\
\hline & Total & 0.102 & 22 & & \\
\hline \multirow{3}{*}{$\begin{array}{l}\text { The takeoff distance (the horizontal } \\
\text { displacement in the takeoff moment } \\
\text { (m) (D3) }\end{array}$} & Between Groups & 0.050 & 3 & 0.017 & \multirow{3}{*}{1.926} \\
\hline & Within Groups & 0.163 & 19 & 0.009 & \\
\hline & Total & 0.213 & 22 & & \\
\hline
\end{tabular}

Table (13)

The significant differences between means with using L.S.D forthe variables related to the body center of mass and distance of takeoff during the takeoff stage

\begin{tabular}{|c|c|c|c|c|c|c|}
\hline \multirow[b]{2}{*}{ Kinematic variables } & \multirow[b]{2}{*}{ Age stage } & \multirow[b]{2}{*}{ Mean } & \multicolumn{4}{|c|}{ Mean Difference } \\
\hline & & & $\begin{array}{c}\text { Under } 16 \\
\text { years }\end{array}$ & $\begin{array}{c}\text { Under } 18 \\
\text { years }\end{array}$ & $\begin{array}{c}\text { Under } 20 \\
\text { years }\end{array}$ & High level \\
\hline \multirow{4}{*}{$\begin{array}{l}\text { The center of mass height } \\
\text { from the ground at touchdown } \\
\qquad(\mathrm{M})(\mathrm{H} 1)\end{array}$} & Under 16 years & 0.85 & & $\uparrow(*) 0.08475$ & $\uparrow(*) 1.10252$ & 0.0953 \\
\hline & Under 18 years & 0.94 & & & 0.01777 & 0.07522 \\
\hline & Under 20 years & 0.95 & & & & $\leftarrow(*) 0.09298$ \\
\hline & High level & 0.86 & & & & \\
\hline
\end{tabular}


Table (14)

The statistical description for some kinematic variables related to takeoff distance during the takeoff stage

\begin{tabular}{|c|c|c|c|}
\hline Kinematic variables & Age stage & Mean & Std. Deviation \\
\hline \multirow{4}{*}{ The takeoff time $(\mathrm{s}) .(\mathrm{T})$} & Under 16 years & 0.129 & 0.0026 \\
\cline { 2 - 4 } & Under 18 years & 0.124 & 0.0020 \\
\cline { 2 - 4 } & Under 20 years & 0.122 & 0.0034 \\
\cline { 2 - 4 } & High level & 0.12 & 0.01 \\
\hline \multirow{3}{*}{$\begin{array}{c}\text { The time from touchdown } \\
\text { to the maximum bending } \\
(\mathrm{s})(\mathrm{t} 1)\end{array}$} & Under 16 years & 0.053 & 0.017 \\
\cline { 2 - 4 } & Under 18 years & 0.053 & 0.0038 \\
\cline { 2 - 4 } & Under 20 years & 0.055 & 0.085 \\
\cline { 2 - 4 } & High level & 0.054 & 0.013 \\
\hline \multirow{3}{*}{$\begin{array}{c}\text { maximum time fro the } \\
\text { moment to takeoff(s) }(\mathrm{t} 2)\end{array}$} & Under 16 years & 0.076 & 0.016 \\
\cline { 2 - 4 } & Under 18 years & 0.071 & 0.0024 \\
\cline { 2 - 4 } & Under 20 years & 0.067 & 0.0072 \\
\cline { 2 - 4 } & High level & 0.076 & 0.012 \\
\hline \multirow{3}{*}{$\begin{array}{c}\text { The flight angle .(degree) } \\
(\theta)\end{array}$} & Under 16 years & 20.17 & 2.14 \\
\cline { 2 - 4 } & Under 18 years & 21.67 & 3.06 \\
\cline { 2 - 4 } & Under 20 years & 21.5 & 2.206 \\
\cline { 2 - 4 } & High level & 23 & 2.92 \\
\hline
\end{tabular}

Table (15)

The analysis of variance for the biokinematic variables related to takeoff during the takeoff stage and flight angle

\begin{tabular}{|c|c|c|c|c|c|}
\hline Kinematic variables & Difference source & $\begin{array}{c}\text { Sum of } \\
\text { Squares }\end{array}$ & df & $\begin{array}{c}\text { Mean } \\
\text { Square }\end{array}$ & $\mathbf{F}$ \\
\hline \multirow{3}{*}{ The takeoff time (s) (T) } & Between Groups & 0.000 & 3 & 0.000 & \multirow[t]{3}{*}{ (*) 3.828} \\
\hline & Within Groups & 0.000 & 19 & 0.000 & \\
\hline & Total & 0.001 & 22 & & \\
\hline \multirow{3}{*}{$\begin{array}{l}\text { The time from touchdown to the } \\
\text { maximum bending }(\mathrm{s})(\mathrm{t} 1)\end{array}$} & Between Groups & 0.000 & 3 & 0.000 & \multirow{3}{*}{0.675} \\
\hline & Within Groups & 0.003 & 19 & 0.000 & \\
\hline & Total & 0.003 & 22 & & \\
\hline \multirow{3}{*}{$\begin{array}{l}\text { The time from the maximum bending } \\
\text { moment to takeoff(s) (t2) }\end{array}$} & Between Groups & 0.000 & 3 & 0.000 & \multirow{3}{*}{0.999} \\
\hline & Within Groups & 0.002 & 19 & 0.000 & \\
\hline & Total & 0.002 & 22 & & \\
\hline \multirow[b]{3}{*}{ The flight angle (degree) $(\theta)$} & Between Groups & 22.072 & 3 & 7.357 & \multirow[b]{3}{*}{1.082} \\
\hline & Within Groups & 129.167 & 19 & 6.798 & \\
\hline & Total & 151.239 & 22 & & \\
\hline
\end{tabular}

Table (16)

The significant differences between means with using L.S.D for the bio kinematic variables related to takeoff during the takeoff stage and flight angle

\begin{tabular}{|c|c|c|c|c|c|c|}
\hline \multirow[b]{2}{*}{ Kinematic variables } & \multirow[b]{2}{*}{ Age stage } & \multirow[b]{2}{*}{ Mean } & \multicolumn{4}{|c|}{ Mean Difference } \\
\hline & & & $\begin{array}{c}\text { Under } 16 \\
\text { years }\end{array}$ & $\begin{array}{c}\text { Under } 18 \\
\text { years }\end{array}$ & $\begin{array}{c}\text { Under } 20 \\
\text { years }\end{array}$ & High level \\
\hline \multirow{4}{*}{ The takeoff time (s) (T) } & Under 16 years & 0.129 & & 0.00500 & $\begin{array}{c}\leftarrow\left(^{*}\right) \\
0.00694\end{array}$ & $\leftarrow(*) 0.00817$ \\
\hline & Under 18 years & 0.124 & & & 0.00194 & 0.00317 \\
\hline & Under 20 years & 0.122 & & & & 0.00123 \\
\hline & High level & 0.12 & & & & \\
\hline
\end{tabular}

\section{Discussion:}

Table (3) and (4) display the contrast analysis and the significance of differences between means using LSD for jump distances for the sample shows:

There are significant differences between ages 16 and 18 years in the jump distance variable favoring the group under 18 years, also there are significant distances between ages under 16 and 20 in the jump distance variable favoring the group under 20 years also there are significant differences between age groups under 16 and the high level in the jump distance variable favoring the group of the high level. It was also clear that there are no significant differences between age groups under 18 and 20 in the jump distance variable. The researchers account that 
to the fact that many contestants of the age group under 18 years in competitions of the age group in results for both groups. Also there are significant differences between age groups under 18, 20 years and first favoring high level contestants' degree in the jump distance variable.

Table (5) displaying value of bio-mechanical values for last two steps of the approach for contestants in study; shows:

Average length for the step before last for age groups (under 16, 18,20 years and high level) was as follows: $(11.2 \mathrm{~m}+0.10 \mathrm{~m}, 2.16+0.08 \mathrm{~m}$, $2.15+0.12 \mathrm{~m}, 2.15 \mathrm{~m}, 0.35 \mathrm{~m})$ consecutively.

Results show rhythm of last two steps a "long short" as stated by Sam, B (1992) : The step before last is longer that last step where center of mass lowers to take the last step as also stated by Margy, G \&Kieth, C (1999) and Milan, C (2001) where length of last two steps 5ranged between (before last : $2.38 \mathrm{~m}-2.50 \mathrm{~m}$, last : $2.05 \mathrm{~m} 2.13 \mathrm{~m}$ ) for higher levels also the study done by Mohamed Abdel Rahim (2005) where average length of step before the last : $2.22 \mathrm{~m}$ and length of last step $: 2.11 \mathrm{~m}$.

The table also shows average resultant velocity for center of mass the moment taking the step before the last for age groups (under 16,18,20 years) were as follows : $(7.04 \mathrm{~m} / \mathrm{s}+0.29 \mathrm{~m} / \mathrm{s}$, $8.28 \mathrm{~m} / \mathrm{s}+0.89 \mathrm{~m} / \mathrm{s}, \quad 8.85 \mathrm{~m} / \mathrm{s}+0.64 \mathrm{~m} / \mathrm{s}$, $9.84 \mathrm{~m} / \mathrm{s},+0.96 \mathrm{~m} / \mathrm{s}$ )

Average resultant velocity for center of mass at the moment of taking the last step for age groups of the study (under 16,18,20 years and high level) was as follows : $(7.19 \mathrm{~m} / \mathrm{s}+0.49 \mathrm{~m} / \mathrm{s}$, $8.08 \mathrm{~m} / \mathrm{s}+0.10 \mathrm{~m} / \mathrm{s}, 8.64 \mathrm{~m} / \mathrm{s}+0.58 \mathrm{~m} / \mathrm{s}, 9.91$ $\mathrm{m} / \mathrm{s}+0.34 \mathrm{~m} / \mathrm{s}$ ) consecutively.

Results were in accordance with what Ahmed SaadEldin Omar (1994) stated as average velocity of approach : $(8.1 \mathrm{~m} / \mathrm{s}+0.408 \mathrm{~m} / \mathrm{s})$ and also Libosh,A et al (1994) where average velocity of approach equals $(7.52 \mathrm{~m} / \mathrm{s}+0.25 \mathrm{~m} / \mathrm{s})$ it also approached results of Seyfarth,A et al (1999) where average velocity of approach equals : $(9 \mathrm{~m} / \mathrm{s})$. It also shows it is below average velocity for higher levels in accordance of studies of: Milan, C et al (1997) where average velocity before takeoff was equal to: $(10.13 \mathrm{~m} / \mathrm{s}$ $+0.5 \mathrm{~m} / \mathrm{s}$ ) for high levels.
Jacoby,E (1982) and Hay, J (1988) stress on the importance of the velocity of approaching which enables the jumper to control his movements to achieve the best takeoff position, this was also pointed out be Mohamed, M\&Hala, M (2001) stressing the importance of velocity in the stage of approaching in particular which enables the jumper to maintain the best position for takeoff to achieve the best distance for his jump.

That is also what Amr, S (2008) stated: Horizontal velocity at approaching and takeoff is the primary and most important factor affecting the horizontal distance achieved. The researcher justifies the decrease in the rate of velocity before takeoff in the sample for all age groups $(16,18,20)$ as due to the young age of the contestants, their short training period and that their heights and weights have not yet reached the point where it satisfied competition requirements as shown in table (1) this agrees with what.

Agoston, S (2002), Abdel Moneim, H (2004) and national Board of Athletics (2004) have stated : the height of the contestant and the length of his lower body in particular gives and indicator to the height pf the center of mass at takeoff which is important indicator in the long jump competitions which affects the increase in the length of the jump through achieving the largest parabolic curve to the center of mass in the flight stage as well as velocity during the last step being a factor determining the distance of the jump.

Tables (6), (7) the analysis of variance and the significant difference between means using L.S.D for Bio-mechanical variables of the last two steps in the approach for contestants in the study, show:

There are significant differences between age groups under 16,18 years in the resultant velocity variable for center of mass at the moment taking the step before last and that of the body at the moment taking that last step favoring the age group below 18 years. Also there are significant differences for age groups below 16 and 20 years in the resultant velocity variable for center of mass at the moment of taking that last step favoring the age group below 20 years. Also there are significant differences between age groups below 16,18,20 
and high level in the resultant velocity of the center of mass at the moment of taking the step before last and the resultant velocity for the center of mass at taking the last step favoring high level group which indicates that as the velocity of approaching increase level of performance is better as stated by Ahmed,S (1994) who points out the importance of velocity of approaching in enhancingperformance at takeoff which confirms what Adrian, M., \& Cooper, J(1995) said in a study taken on a medium level group with an average velocity of approaching equal to $(8.1 \mathrm{~m} / \mathrm{s})$ and a study by Milan,C et al (1997) where average velocity before takeoff equals $(10.13 \mathrm{~m} / \mathrm{s})$ for advanced levels average velocity of step before the last $=(8.54 \mathrm{~m} / \mathrm{s} 0$ and of last step $(8.83 \mathrm{~m} / \mathrm{s})$ for level below advanced.

Table (6), (7) also show no significant differences between age groups below 18 and 20 years in resultant velocity for center of mass at the moment of taking step before the last and last step and that is due the fact that height and weight of constant of both groups is close in rules also due to the large number of constants of both age groups below 18, 20 years (3 constants) as the competitive rules permit younger jumpers to complete in competitions of larger age group.

Average horizontal velocity for center of mass at moment of touchdown for age group in study (below 16, 18, 20, high level) was as follows: $(7.62 \mathrm{~m} / \mathrm{s} \pm 0.41 \mathrm{~m} / \mathrm{s}, \quad 8.38 \mathrm{~m} / \mathrm{s} \pm 0.39 \mathrm{~m} / \mathrm{s}$, $8.83 \mathrm{~m} / \mathrm{s} \pm 0.56 \mathrm{~m} / \mathrm{s}, \quad \quad 9.67 \mathrm{~m} / \mathrm{s} \pm 0.29 \mathrm{~m} / \mathrm{s}$ ). Consecutively.

These results were below high levels for high level as stated by Herald,M \&Gert,P (1997) where horizontal velocity of center of mass at touchdown $=(10.66 \mathrm{~m} / \mathrm{s} \pm 0.28 \mathrm{~m} / \mathrm{s})$

Also as Milan, C (2000) stated $=(9.46 \mathrm{~m} / \mathrm{s})$ and Abdel Moneim, H (2004) $=(10.97 \mathrm{~m} / \mathrm{s})$ horizontal velocity for center of of mass for age group below 20 approached what Muraki, $Y$ et al (2008) mentioned $=(9.22 \mathrm{~m} / \mathrm{s} \pm 0.46 \mathrm{~m} / \mathrm{s})$ at touchdown researchers attribute that decrease in horizontal velocity for center of mass at touchdown to the decrease in approaching velocity as velocity of takeoff in the resultant velocity of approach as stated by Bastwisi, A (1997) saying that level of performance in the long jump depends on 2 factors : velocity gained from approach connected with takeoff and power gained from takeoff connected to the light which agrees with Rogers , J (2004) stating that the contestant has to shift velocity gained from the approach to vertical velocity during takeoff to increase distance of hump, also Muraki,Yet al (2008) stress on the importance of horizontal velocity for center of mass at touchdown as they are strongly connected $(r=$ 0.86) which explains development of performance for study groups and attributing high results to the high velocity of center of mass at touchdown for older contestants groups more than younger age groups.

Average vertical velocity of center of mass at touchdown for age groups in study (below $16,18,20$ years , high level) were as follows: $(0.48 \mathrm{~m} / \mathrm{s} \pm 0.44 \mathrm{~m} / \mathrm{s}, 0.43 \mathrm{~m} / \mathrm{s} \pm 0.17 \mathrm{~m} / \mathrm{s}, 0.3$ $\mathrm{m} / \mathrm{s} \pm 0.15 \mathrm{~m} / \mathrm{s}, 0.53 \mathrm{~m} / \mathrm{s} \pm 0.4 \mathrm{~m} / \mathrm{s}$ ) consecutively.

This degree with what Milan, C (2000) stated as velocity equals $(0.26 \mathrm{~m} / \mathrm{s})$ at touchdown and Abdel Moneim, H (2004) velocity $=(0.36 \mathrm{~m} / \mathrm{s})$ at touchdown this is attributed to the fact that vertical velocity does not greatly affect distance of jump as stated by Luhtananen,P\&Komi,P (1979) and Hay,J (1986) the jumper lowers center of mass before takeoff.

Average velocity of center of mass at touchdown for age groups in study (below $16,18,20$ years, High level) are $(6.63 \mathrm{~m} / \mathrm{s} \pm 0.43$ $\mathrm{m} / \mathrm{s}, 8.4 \mathrm{~m} / \mathrm{s}+-0.39 \mathrm{~m} / \mathrm{s}, 8.84 \mathrm{~m} / \mathrm{s} \pm 0.56 \mathrm{~m} / \mathrm{s}$, $9.70 \mathrm{~m} / \mathrm{s} \pm 0.31 \mathrm{~m} / \mathrm{s}$ ) consecutively.

There are below results obtained for high level from study of Harold, M\&Gert,P (1997) as velocity reached $(10.66 \mathrm{~m} / \mathrm{s})$ at touchdown, Abdel Moneim, H (2004): velocity at touchdown $(10.87 \mathrm{~m} / \mathrm{s})$ results of high level confirm what Milan, C2000 said that velocity $(9.7 \mathrm{~m} / \mathrm{s})$ at touchdown. An enhancement in resultant velocity at touchdown favoring older age groups and increasing the distance of jump as stated in table 2 confirming what Luhtananen,P\&Komi,P (1997) , Hay,J et al (1986) and Lees,A et al (1994) stressing that velocity of center of mass at touchdown in long jump during takeoff is of great importance to distance of jump.

Average horizontal velocity of center of mass at takeoff for age groups (below 16 ,18, 20 years 
and high level ) are: $(6.54 \mathrm{~m} / \mathrm{s} \pm 0.40 \mathrm{~m} / \mathrm{s}, 7.43$ $\mathrm{m} / \mathrm{s} \pm 0.31 \mathrm{~m} / \mathrm{s}, 7.77 \mathrm{~m} / \mathrm{s} \pm 0.49 \mathrm{~m} / \mathrm{s}, 8.34 \mathrm{~m} / \mathrm{s} \pm$ $0.45 \mathrm{~m} / \mathrm{s}$ ) consecutively.

Usama, M (2004) in his study stated that horizontal velocity of center of mass at takeoff $=(7.85 \mathrm{~m} / \mathrm{s} \pm 0.44 \mathrm{~m} / \mathrm{s})$ which is less than results of high level group (in study) were also it was below average for high level group as compared to world records as stated by Milan, $\mathrm{C}$ et al (1997) where velocity at takeoff $=(8.95$ $\mathrm{m} / \mathrm{s})$ and $(8.83 \mathrm{~m} / \mathrm{s})$ as stated by Harold, $\mathrm{M}$ \&Gert,p (1997) and $(8.10 \mathrm{~m} / \mathrm{s})$ according to Milan, C (2000) and $(9.63 \mathrm{~m} / \mathrm{s})$ according to Abdel Moneim, H (2004) and $(8.25 \mathrm{~m} / \mathrm{s})$ according to Mohamed,A (2005) and Muraki,Y et al (2008) stated velocity as : $(8.08 \mathrm{~m} / \mathrm{s})$.

An enhancement of velocity is evident at takeoff favoring older age groups as seen in tables 9,10 which stresses the importance of this factor in performance as indicated by Muraki,Y et al (2008) : horizontal velocity of center of mass at takeoff is of great significant to distance of long jump $(r=0.83)$.

Average vertical velocity of center of mass at takeoff for age groups in study $(2.44 \mathrm{~m} / \mathrm{s} \pm 0.34$ $\mathrm{m} / \mathrm{s}, 2.94 \mathrm{~m} / \mathrm{s} \pm 0.48 \mathrm{~m} / \mathrm{s}, 3.06 \mathrm{~m} / \mathrm{s} \pm 0.38 \mathrm{~m} / \mathrm{s}$, $3.44 \mathrm{~m} / \mathrm{s} \pm 0.43 \mathrm{~m} / \mathrm{s}$ ) consecutively.

These confirm results for high level by Mohamed,A (2005) $(0.295 \mathrm{~m} / \mathrm{s})$ results are lower than those mentioned by Milan, $\mathrm{C}$ et al (1997) $(3.35 \mathrm{~m} / \mathrm{s} \pm 0.3 \mathrm{~m} / \mathrm{s})$. and Milan, C $(2000)=(3.9 \mathrm{~m} / \mathrm{s})$ and Abdel Moneim, $\mathrm{H}$ $(2004)=(3.45 \mathrm{~m} / \mathrm{s} \pm 0.3 \mathrm{~m} / \mathrm{s})$ but the increase in velocity is a proof of enhancement of performance stressing the importance of vertical velocity of center of mass at takeoff in increasing distance of jump, by transforming a part of the horizontal velocity of approach to vertical velocity at takeoff confirming what Luhtananen,P\&Komi,P (1979), Hay,J (1986) , Hay,Jet al (1986), Lees, A et al (1994) said, velocity of center of mass at takeoff is of great importance to the distance of center of mass increase during approaching and vertical velocity is gained at takeoff confirming what Rogers,J (2004) said ,long jump contestants have to transform a portion of horizontal velocity gained at approaching to vertical velocity during takeoff to increase distance of jump.
Average velocity of center of mass at takeoff for age groups of study below $(16,18,20$ years and high level) are $(3.99 \mathrm{~m} / \mathrm{s} \pm 0.4 \mathrm{~m} / \mathrm{s}, 9.03 \mathrm{~m} / \mathrm{s} \pm$ $0.32 \mathrm{~m} / \mathrm{s}$ ) consecutively.

These results confirm what Ahmed, S (1994) said for results of group below 18,20 years as velocity at takeoff $=8.67 \mathrm{~m} / \mathrm{s} \pm 0.485 \mathrm{~m} / \mathrm{s}$ ), resultant velocity approaches what Mohamed ,A (2005) results $(8.76 \mathrm{~m} / \mathrm{s})$ high level results confirm Hay, J et al (1987) : $(9.2 \mathrm{~m} / \mathrm{s}-10 \mathrm{~m} / \mathrm{s})$ and Milan,C et al (1997) : $(9.56 \mathrm{~m} / \mathrm{s} \pm 0.5 \mathrm{~m} / \mathrm{s})$ and Abdel Moneim, H (2004) $(10.17 \mathrm{~m} / \mathrm{s} \pm 0.95$ $\mathrm{m} / \mathrm{s}$ ), This is attributed to the fact that as age and experience of jumper increase the more he is able to make use of velocity gained at approach to use in takeoff as in table 2 confirming what Luhtananen,P\&Komi,P (1979) , Hay,J (1986), Hay,J et al (1986), Lees,A et al (1994) , Rogers,J (2004) said, which is also clear in tables $(5,6,7)$ stating that resultant velocity increase in the last two steps of approach and enhancement was always for older age groups.

Tables 9 and 10 which analyze show the significant and the least significant differences of between velocities of center of mass during the takeoff stage of the contestants under study show:

There are significant differences between age groups under 16 and 18 years in the horizontal variable center of mass touchdown, the horizontal velocity of center of mass the moment takeoff, the vertical velocity of center of mass at the moment of takeoff, the outcome of the velocity of the center of mass at the moment of takeoff, in favor of the age group under 18 years, also there are significant differences between age groups under 16 years and under 20 years in the variables of the horizontal velocity of the center of mass the moment it lands on the ground, the outcome of velocity of the center of mass the moment it lands on the ground, the horizontal velocity of the center of mass the moment takeoff , the vertical velocity of the center of mass the moment takeoff, and the outcome velocity of the center of mass the moment of takeoff in favor of the age groups under 20 years , there are significant differences between the age groups under 16, 18, 20 years and the high level in variables of horizontal velocity and the 
outcome of the center of mass the moment of landing and the horizontal velocity and the resultant velocity of the center of mass the moment of takeoff, This difference in velocity variables during the takeoff stage might be due to what was mentioned in tables 5,6,7 about the difference in the velocity of approaching in the last two steps which was in favor of the older age groups which indicates the importance of the approach velocity specially the last steps in order for the contestant to reach the highest rate of velocity while fulfilling the needs of the takeoff stage of changing the position of the body to be able to achieve the best rate of achievement which was confirmed by Luhtananen,P\&Komi,P (1979),Hay,J (1986), Hay,Jet al (1986), Lees,Aet al (1994), Rogers,J (2004) AbdelMoniem, H (2004), Muraki, Yet al (2008) which also agrees with what Hay,J (1994) mentioned about the importance of increasing he velocity at the end of the approach to the limit that could be effectively used in the takeoff stage.

From the same tables number (9) and (10) it is noted that there are no significant differences between the age groups under 18 and under 20 years in the variables of horizontal velocity and resultant velocity of the center of mass the moment of landing, the resultant velocity, the horizontal and vertical velocities of the center of mass the moment of takeoff, which might be due to the rapprochement between the performance of the contestants thin weight; heights and also the velocity of approach at the end of the approach as one of the important indicators that affect 6the velocity of takeoff and therefore the distance covered in the jump as shown in tables (1), (5) and from the same tables (9), (10) it is clear that there are no significant differences between the age groups under 18, under 20 years and the high level in the variable of the vertical velocity of the center of mass at the moment of takeoff.

Table (11) which are showing the variables of the height of the center of mass and the distance of performing the takeoff during the takeoff stage for the contestants under study shows.

The average height of the center of mass from ground at the moment of landing for age groups under study (under 16, under 18, under 20 years, and the high level) were as follows: $(0.85 \mathrm{~m}+$
$0.06 \mathrm{~m}, 0.94 \mathrm{~m}+0.05 \mathrm{~m} 0.95 \mathrm{~m}+0.03 \mathrm{~m}, 0.86 \mathrm{~m}$ , $0.1 \mathrm{~m}$ ) respectively

The age group under 20 matched what Milan, C et al (1997) mentioned where the height of the center of mass from the grunt at the moment of landing was $(0.094 m+0.04 m)$ for the lower level, as for the higher level, the height of the center of mass from the ground at the moment of landing was $(0.99 m+0.07 \mathrm{~m})$ and also what Abdel Moneim, $\mathrm{H}$ mentioned, where the height of the center of mass from the ground at the moment of landing was $(0.956 m+0.13 m)$

The average height of the center of mass from the ground at the moment of takeoff for the age groups under study (under 16, under 18, under20, high level) were as follows: $(1.05 \mathrm{~m}+$ $0.08 \mathrm{~m}, 1.17 \mathrm{~m}+0.14 \mathrm{~m}, 1.18 \mathrm{~m}+0.05 \mathrm{~m}$, $1.11 \mathrm{~m}+0.09 \mathrm{~m}$ ) respectively

And from these results, it is clear that the height of the center of mass from ground at the moment of takeoff for the age group under 18 years and under 20 years are close, which matches that Milan, C et al (1997) mentioned, as the height of the center of mass from the ground at the moment of takeoff was $(0.22 \mathrm{~m}+$ $0.08 \mathrm{~m})$ and else what Abdel Moneim, $\mathrm{H}$ mentioned (2004) where the height of the center of mass was at the moment of table off was $(1.20 \mathrm{~m}+0.0419 \mathrm{~m})$ and also what Milan, C (2000) mentioned as the height of the center of mass from the ground at the moment of takeoff was $(1.23 \mathrm{~m})$.

The average difference between the height of the center of mass of the begging of the takeoff and at the end of the takeoff for the age groups under study (under 16, under 18, under 20 years and the high level0 were as follows:

$+0.05 \mathrm{~m}, 0.28 \mathrm{~m}+0.10 \mathrm{~m}, 0.23 \mathrm{~m}+0.05 \mathrm{~m}$, $0.25 \mathrm{~m}+0.05 \mathrm{~m}$ ) respectively.

Which matches for the high level with Milan, C et al (1997) where the average difference between the heights of the center of mass the moments the takeoff begins and ends was $0.23 \mathrm{~m}$, Abdel Moneim, H (2004) where the average difference between the heights of the center of mass at the beginning of the takeoff and the end of it was $(0.247+0.048 \mathrm{~m})$, and also with Ahmed, S (1994) where the average difference between the height of the center of 
mass at the beginning of the takeoff and the end of it as $(0.22+0.021 \mathrm{~m})$

The average distance of performing the takeoff (the horizontal displacement during the takeoff) for the age groups under study (under 16, under 18 , under 20 years and the high level) were as follows : $(1.05 \mathrm{~m}+0.13 \mathrm{~m}, 1.03 \mathrm{~m}+0.08 \mathrm{~m}$, $0.93 m+0.06 m, 0.99 m+0.08 m)$ respectively.

Those results show that they are less than what Abdel Moniem, H(2004) as the average distance of the takeoff (the horizontal displacement during the takeoff stage) was $(0.268 m+0.12 m)$ and that might be due to the difference in age and experience of the current group under study as they are younger and less experienced.

Table (12), (13) Analysis of variance and the significance of the difference between the average using LSD between the variables of the height of the center of mass and the distance of performing the takeoff during the stage of mounting of the contestants under study.

There are significant differences between the age groups under 16 years and under 18 years $m$ the variable of height of the center of mass the moment of landing in favor of the under 18 y4ears age groups under 16, under 20 years $m$ the variable of height of the center of mass from the ground at the moment of landing in favor of 6the under 20 age group, the5re are also significant differences between the age group under 20 years and 6the high level in the variable of the height of the center of mass from the ground the moment of landing in favor of the age group under 20 years.

Which indicates the importance of the height of the center of mass from the ground at the moment of landing and the moment of takeoff in achieving the widest parabola for the center of mass during the flight which affect the distance of the long jump which was mentioned by Agoston, S (2002) , Abdel Moneim, H (2004), the international union of athletics (2004).

Tables (12), (13) also show that there are no significant differences between age groups under 16, under 18, under 20 years and the high level in the variables of the height of the center of mass from the ground at the moment of landing height of center of mass at the moment of the takeoff, the difference between the heights of the center of mass at the beginning and the end of the takeoff and the takeoff distance, which might be due to the reproach in the heights of the contestants as shown in table (1) which matches what Agoston, S (2002) Abdel Moneim, H (2004), the international union of athletics (2004) said where the height of the contestant and his lower body especially may give indicator about the height of the center of mass at the takeoff and also to the reproach of the vertical velocity of the center of 6the massa6t the moment of the takeoff as shown in table (8).

Table (14) shows the variables of the time during the takeoff and the angle of flight of the contestants under study :

The average takeoff time of the age groups (under 16, under 18, under20 years and the high level) were as follows: $(0.129 \mathrm{~s}+0.0026 \mathrm{~s}$, $0.124 \mathrm{~s}+0.0020 \mathrm{~s}, 0.122 \mathrm{~s}+0.0043 \mathrm{~s}, 0.125+$ $0.01 \mathrm{~s})$ respectively.

The average time from the moment if touching the ground until the most bending for age groups under study (under 16, under 18, under 20 years and the high level) were as follows: $(0.053 \mathrm{~s}+0.017,0.053 \mathrm{~s}+0.0038 \mathrm{~s}, 0.055 \mathrm{~s}+$ $0.0085 \mathrm{~s}, 0.045 \mathrm{~s}+0.013 \mathrm{~s})$ respectively.

The average time from the moment of the most bending until the moment $\mathrm{o}$ the takeoff for the age groups understudy (under16, under 18, under 20 years and the high level) were as follows : $(0.076 \mathrm{~s}+0.016 \mathrm{~s}, 0.071 \mathrm{~s}+0.0024 \mathrm{~s}$, $0.067+0.00725,0.076 \mathrm{~s}+0.012 \mathrm{~s})$ respectively

These results match with Hey,J (1988) where the takeoff time was ranging between $(0.11 \mathrm{~s}$ to 0.13s) and Suliman, H \&Owais, G (1989) where the takeoff time ranged between $(0.10 \mathrm{~s}$ to $0.13 \mathrm{~s})$ and Ahmed, S (1994) where takeoff time ranged between $(0.11 \mathrm{~s}$ to $0.13 \mathrm{~s})$ and Mohamed,A (2005) where the takeoff time was (0.11 to 0.135 ) and age of practice and experience of the contestants is shown in tables (1) and (2).

The average angle of flight for the age groups under study (under 16, under 18, under20 years and the high level) were as follows: $(20.17 \mathrm{o}+$ 2.14 o, $21.67 \mathrm{o}+3.06 \mathrm{o}, 21.5 \mathrm{o}+2.26 \mathrm{o}+23 \mathrm{o}+$ $2.92 \mathrm{o}$ ) respectively .

These results match Milan,C et al (1997) where the angle of flight was $(20.6$ o +2.8 o) Harald, 
M , Gert, $\mathrm{P}(1997)$ where the angle of flight was (21 o+ 1.77 o) Ahmed, S (1994) where the angle of flight was (19.75 o+1.76 o), Mohamed,A (2005) where the angle of flight was (21.80) and they also match what Amr,S (2008) pointed training the contestants to takeoff at a certain angle of (19.75 o to $22.14 \mathrm{o})$.

Table (15) and (16) which analyze the difference and the significant difference between the averages using L.S.D for the variables of time during the takeoff and flight angle for the contestants under study:

There are significant differences between age groups of under 16, under 20 years in the variable of elevation time in favor of the age group under 20 years. There are also significant differences between the age groups under 16 years and the main 6team in the variable of elevation time in favor of the high level. Which might be due to the upgrade in the level of the contestants and the increase in this in this experience which matches Hay,J (1988) where the elevation time was $(0.11 \mathrm{~s}$ to $0.13 \mathrm{~s})$ and Suliman, H\&Owais, G (1989) where elevation time was $(0.10 \mathrm{~s}$ to $0.13 \mathrm{~s})$. Ahmed, $\mathrm{S}$ (1994) Where the elevation time was $(0.11 \mathrm{~s}$ to $0.13 \mathrm{~s})$ for the higher level, where asForeman,K (1982) adds that the elevation time for the less experiences long jumpers takes $(0.18 \mathrm{~s}$ to $0.20 \mathrm{~s})$ and Adrian, M. , \& Cooper , j (1995) that the elevation time for the lower level contestants takes about ( 0.13 to $0.14 \mathrm{~s})$.

\section{Conclusions:}

1. Horizontal and resultant velocityrate directly before takeoff increases as the age group is older, though there is no significant difference between the age groups of under 18 and under 20 years.

2. Horizontal, vertical and resultant velocityrate at the moment of takeoff at the elevation increases as the age group gets older, though there was no significant difference between age groups of under 18 , under 20 years old and the high level, but there was a major difference between under 16 years age group and the rest of the age groups.

3. There is a great rate of losing horizontal and resultant velocityby the contestants of the four categories at the elevation (the moment of takeoff) than touching the ground directly (the moment of takeoff) than touching the ground directly before the elevation ranging between $0.40 \mathrm{~m} / \mathrm{s}$ to $0.67 \mathrm{~m} / \mathrm{s}$.

\section{Recommendations:}

1. Putting training programs to enhance the performance of those who lack velocity, by enhancing the horizontal and vertical velocity at the moment of losing contact with the ground.

2. Paying attention to enhancing the rhythm of the last two steps of the approach in terms of length and velocity.

3. Using Bio-mechanical motion analysis to performance levels to obtain a dynamic way to enhance the performance skill to offer the necessary data base for the Bio-mechanical variables as basic references to a wide range of trainer's contestants and researchers.

\section{References:}

1. Abdel Moneim, I.: An Analytical Study for some Kinematic values in the Long Jump for high level contestants (men). A.R.E. Scientific Magazine Theories and Applications, Issue 50, Faculty of Physical Education (men), University of Alexandria, 2004.

2. Adrian, M. , \& Cooper, j: "Biomechanics of Human Movement". W .C. B. Brown \& Benchmark press. USA, 1995.

3. Agoston, S.: "Long jump with super a maximal \& normal velocity", new studies in athletics by iaaf $2: 17,2002$.

4. Ahmed, S.: EnhancingLoss of Velocity of approaching and its effect on some kinematic variables for distance of long jump, An unpublished PHD thesis, Faculty of physical education (men), University of Alexandria, 1994.

5. Alexander, R. \& Vernon, A: "The dimensions of knee muscle \& the Force they Exert" .J. Human Movement Studies vol 1, pp.45 -113 1995.

6. Amr, S.: Developing Level of Performance from the Bio-mechanic view point in the light of optimal performance rates in the Long Jump, 
4th Regional Conference for the International Council of Health, Physical education, recreation, sports and motor expression in the Middle East, Faculty of Physical Education (men), University of Alexandria, 2008.

7. Bastawisi, A.: Track and field Races, House of Arabic Thought, Cairo, 1997.

8. Bhowmick: "Biomechanical Features Of the takeoff in the running long jump". University of kalyanlIndia.Vol 14 no 4 oct.1992.

9. DempesterW,et al: "The anthropometry of manual work space for the seated Subjects Amer ,g., physathrop" . No 17:289-317.

10. Foreman,K.,: "Coaching track and field techniques" , Brown Co, publishing , 4th., ed.,pp ,141-156. 1982.

11. Gamal, M. \&Nahed, A.: Metrological Basis for evaluating level of physical, skill and plan performance for athletes. Munshaat Al Maarif, 2007.

12. Harald, M, Gert, P: "Long jump, Biomechanical research project at the VI the world championships in athletics Athens1997", preliminary report NSA , VL.12,Issuen, 2-3 September pp56, 1997.

13. Hay, J: "The approach run in long jump, track techniques" , the official technical publication of the athletics congress , U.S.A , pp 3339-3362, 1988.

14. Hay, J: "The current status of research on the Biomechanics of the long jump" , track technique , summer, No128 , pp 4089-4093 , 1994.

15. Hay, J: "The biomechanics of the long jump". ink.B.pandolf (ed) . Exercise and sports science Reviews (volume 14), pp 431-446, New Yourk, Macmillan publishing co, 1986.

16. Hay, et al: "The technique of elite male long jumpers". Journal of biomechanics, 19 (10), 855-866, 1986.

17. Hay,.et al: "Biomechanics of elite long jumping track technique" 101, .1987.

18. Jacoby , E: "Applied techniques in track and field", Leisure press, west point, New York, pp141-157, 1982.

19. Kassem, H.: Encyclopedia of Field and Track "Running, Hurdles, steeples, Jump, Vault,
Throw, Cast, Complex Games" House of Thought Press and Publishers, Jordan, 1998.

20. Lees, A. et al: "A biomechanical Analysis of last stride touchdown and takeoff characteristics of the men's long jump", journal of applied Biomechanics, Vol. 10, No1, 1994.

21. Liboshi,A. et al: "Biomechanical analysis of the techniques for the world's best high jumpers (in Japanese)", in Japan Association of athletic federations (ed), the techniques of the world top athletes (research report of the 3rd IAAF world championships in athletics, Tokyo), pp 169-184, 1994.

22. Luhtananen, p. \&komi, p.: "Mechanical power and takeoff characteristics of the men's long jump", journal of applied Biomechanics, 10, 61-78, 1979.

23. Margy, G. \&Keith, C.: "The effect of steering on stride pattern \& velocity in long jump", NSW, Australia, 1999.

24. Milan, C.: "Kinematic and Dynamic model of the long jump", track coach, winter, 150, pp 4789-4795, 2000.

25. Milan, C.: "Cathy freeman's sprinting technique", track coach, summer 2001.

26. Milan, C. et al: "Kinematic - Dynamic analysis of the takeoff action in the long jump", track coach, spring, 139, pp 4443-4795, 1997.

27. Mohamed, A.: Evaluating Performance of the National Team of Libya in the Long Jump competition, an unpublished $\mathrm{PhD}$. Thesis, Faculty of Physical Education (men), University of Alexandria, 2005.

28. Mohamed, A. \&Hala, M.: Evaluating Mechanical Performance for Long Jumpers (women) in Egypt, Scientific Magazine Theories and Applications issue 43, Faculty of Physical Education (men), University of Alexandria, 2001.

29. Muraki,Y. et al: "Joint torque and power of the takeoff leg in the long jump", (in Japanese) international journal of sport and health science Vo 16, pp 21-32, 2008.

30. National Board of Athletics: Theories of Training, A publication for coaches of Second Level in Certificate system, and Coach education in the national Board of Athletics, 
translated by regional Center of development in Cairo- issue 4 January 2004.

31. Rogers,J.: "USA track \& field coaching manual", (in Japanese) pp, 152-166, trans. H, Sawamura. K, Sawaki, M, Ogata, and K, Aogama ,Tokyo , Rikujokyogi ,Co, and Shuppangeijutsu,Co, 2004 .

32. Sam, B.: "The long jump", coaches review track \& field, volume 72 issue 4, 1992.

33. Seyfarth,A. et al: "Dynamics of the long jump", journal of Biomechanics, 32, pp 12591267, 1999.
34. Suliman, H. \&Owais, G.: Athletics between Theory and Application, Al Tayseer press, Cairo, 1989.

35. Usama, M.: The Effect of using the enhanced stretching device to increase the effectiveness of takeoff and enhancingresults of Long Jump contestants. An unpublished PHD thesis, Faculty of Physical Education (men), University of Alexandria, 2004.

36. Wood, j . et al: "Quantification arm control surface modeling" .journal of Biomechanics vol.22, no .3, pp $273-292$ (1989). 